\title{
In vitro Rumen Degradability Study of Wet Brewer's Spent Grain by Modified Rumen Simulation Technique (TANUVAS-RUSITEC ${ }^{\text {TM }}$ )
}

\author{
V. Thavasiappan ${ }^{1 *}$, K. Nanjappan ${ }^{2}$, P. Visha ${ }^{2}$, R. Ezakial Napolean ${ }^{3}$, \\ P. Selvaraj ${ }^{2}$ and K.A. Doraisamy ${ }^{4}$
}

${ }^{1}$ Sheep Breeding Research Station, Sandynallah, The Nilgiris, Tamil Nadu, TANUVAS, India

${ }^{2}$ Department of Veterinary Physiology, Veterinary College and Research Institute, Namakkal, TANUVAS, India

${ }^{3}$ Teaching Veterinary Clinical complex, Veterinary College and Research Institute, Namakkal, TANUVAS, Chennai, India

${ }^{4}$ Veterinary University Training and Research Centre, Salem, TANUVAS, Chennai, India

*Corresponding author

\section{A B S T R A C T}

Keywords

WBSG, In vitro study, TANUVAS RUSITEC $^{\mathrm{TM}}$, Dry matter and Nitrogen degradability

\section{Article Info}

Accepted:

10 April 2020

Available Online:

10 May 2020
Wet brewer's spent grain (WBSG) is the extracted residue remaining after grains have been fermented during beer making process. The annual WBSG production in India is approximately 0.4 million tones and can serve as a good feed ingredient for livestock especially for ruminants as it is a good source of protein with a crude protein content ranging from 25 to 34 per cent and has 7 to 10 per cent crude fat. In vitro dry matter and nitrogen degradability of wet brewer's spent grain were determined using a modified rumen simulation technique (TANUVAS-RUSITEC ${ }^{\mathrm{TM}}$ ). The effective DM and nitrogen degradability of WBSG were 40.72 and 33.40 per cent, respectively. The rumen degradable protein (RDP) was 32.72 per cent and rumen undegradable protein (RUP) was 54.93 per cent. Wet brewer's spent grain containing 27.47 per cent crude protein with 54.93 per cent rumen undegradable protein (RUP) can be effectively used as a potential bypass protein source in the ruminant diet.

\section{Introduction}

India is basically an agricultural country and about 70 per cent of its people live in villages. Their livelihood is dependent mainly on agriculture and animal husbandry. Though
India has a huge livestock population of over 512 millions, which includes 135.17 millions of goat population (Nineteenth Livestock Census, 2012), the production of per animal milk, meat and other livestock products are still the lowest in the world due to diminished 
adequate supply of fodder to the livestock. However, increasing human demands has led to a considerable decrease in available farming lands due to the increase in the cropping for human foods. Agro-industrial byproducts are derived from the agricultural industry due to processing of the main products. They are less fibrous, more concentrated, highly nutritious and less costly as compared to crop residues (Aguilera, 1989). There is an increase in the availability of agro-industrial byproducts such as molasses, brewer's grains, palm oil cake and winery mash, which are not fully utilized in livestock feeding (Devendra, 1983). Wet brewers spent grain (WBSG) is the extracted residue remaining after grains have been fermented during beer making process. The annual WBSG production in India is approximately 0.4 million tones. The protein, fibre, and energy concentration of wet brewer's gain make them a suitable supplement in both ruminant and nonruminant diet. Wet brewer's grains (WBG) though have low dry matter, however, on dry matter basis, they have high content of total digestible nutrients (TDN) (Hersom, 2006) having an energy value of 71 to 75 per cent. WBG contain 7 to 10 per cent crude fat and are a good source of protein with a crude protein content ranging from 25 to 34 per cent. The concentration of rumen degradable protein ranges from 28 to 43 per cent with a mean of 35 per cent, indicating that WBG are good source of rumen undegradable or "bypass protein" (Thomas et al., 2013). In dairy cattle, brewer's grain feeding up to 30 per cent dry matter intake increased the quality and quantity of milk (West et al., 1994). In feedlot cattle, better performance and growth rates were noticed (Ewing, 1997). However, effective degradability of nitrogen, RUP and RDP of wet brewers spent grain in the diets has not been exhaustively studied and documented. To consider above fact, the study was carried to determine the rumen undegradable protein fraction in the wet brewer's spent grain by In vitro using a modified rumen simulation technique (TANUVAS-RUSITEC $^{\mathrm{TM}}$ )

\section{Materials and Methods}

The wet brewer's spent grain produced by the Mohan Breweries, Chennai were procured at weekly intervals and were used for the in vitro studies and which is consisted of mixture of grains including malted wheat, barley, maize (corn), rice etc. In vitro dry matter and nitrogen degradability of wet brewer's spent grain were determined using a modified rumen simulation technique (TANUVAS-RUSITEC $^{\mathrm{TM}}$ Plate-1) as described by Czerkawski and Breckenridge (1977).

After slaughter, rumen digesta were collected from five adult does, thoroughly mixed and transported to the laboratory (within $30 \mathrm{~min}$ ) in a pre-heated vacuum flask. Rumen liquor was strained through a double-layered muslin cloth into a $\mathrm{CO}_{2}$ filled beaker. Each reaction vessel of the RUSITEC was charged with 500 $\mathrm{ml}$ of strained rumen liquor and $200 \mathrm{ml}$ of artificial saliva (McDougall, 1948). One nylon bag (130x80 mm size, pore size $20 \mu \mathrm{m}$ ) containing approximately $80 \mathrm{~g}$ of rumen digesta solids (fibrous fraction obtained after straining the rumen content) and another nylon bag with $10 \mathrm{~g}$ DM feed to be tested were placed into the perforated feed container and the assembly was placed in the reaction vessel which was filled up to the brim with distilled water, making the total volume of the container to one liter.

Artificial saliva (Sodium hydrogen carbonate $(9.80 \mathrm{~g})$, disodium hydrogen ortho phosphate $(4.97 \mathrm{~g})$, potassium chloride $(0.57 \mathrm{~g})$, sodium chloride $(0.47 \mathrm{~g})$, magnesium chloride $(0.123 \mathrm{~g})$ and calcium chloride $(0.04 \mathrm{~g})$ per liter of artificial saliva) was pumped at a 
constant rate of infusion $(0.55 \mathrm{ml} / \mathrm{min})$ into each reaction vessel using a peristaltic pump. The effluent was collected in effluent collection vessel (containing few drops of saturated $\mathrm{HgCl}_{2}$ solution). During the adaptation period, the apparatus containing rumen digesta and feed sample was run for 24 $\mathrm{h}$ maintaining strict anaerobic condition. After $24 \mathrm{~h}$ of incubation, i.e., at the end of first day incubation and on the second day, the original solid inoculum was removed and a fresh nylon bag containing $10 \mathrm{~g}$ feed was placed in the feed container. On subsequent days, the bag that was already kept for 2 days in the reaction vessel was removed and a new bag of feed was introduced. This procedure was repeated every morning to achieve an incubation time of $48 \mathrm{~h}$ for each sample. During collection period, ten grams of fresh feed samples were taken and macerated in a homogenizer. The samples were placed in separate nylon bags (in triplicate) and inserted in the perforated slots of reaction vessel. They were incubated for $0,3,6,9,12,24,36,48$ and $72 \mathrm{~h}$ in the reaction vessel of RUSITEC. At the end of the incubation period, the bags were removed from the reaction vessel, drained, squeezed and washed twice with $40 \mathrm{ml}$ of artificial saliva. The washed saliva was returned to the respective reaction vessel. The removed bags were further washed and dried at $60^{\circ} \mathrm{C}$ for $48 \mathrm{~h}$.

\section{In vitro dry matter degradability}

Loss in weight of nylon bag, after $0,3,6,9$, $12,24,36,48$ and $72 \mathrm{~h}$ of incubation in RUSITEC followed by washing and drying, was recorded to calculate dry matter disappearance.

The in vitro degradability of samples was calculated using the following formula and expressed as percentage on dry matter basis. (Weight of bag with samples before incubation) -
In vitro degradability $=$

(Weight of the bag with samples after incubation)

Weight of samples before incubation

The effective degradability of dry matter was calculated from the results of the dry matter degraded at various time intervals and by fitting the data to exponential equation of Orskov and Mc Donald (1979) as mentioned below

$P=a+b\left(1-e^{-c t}\right)$

Where

$\mathrm{P}=$ Effective degradability

$\mathrm{a}=$ Soluble fraction in percentage

$\mathrm{b}=$ Insoluble but potentially degradable fraction in percentage

$a+b=$ Value of potential degradability of the material in percentage

$\mathrm{c}=$ degradation rate, expressed as percentage/h

(e is a constant in exponential equation)

$\mathrm{t}=$ time

\section{In vitro nitrogen degradability}

The nitrogen content of residues obtained after incubation of $0,3,6,9,12,24,36,48$, and $72 \mathrm{~h}$ were estimated (AOAC, 2012). The residual dry matter in the nylon bag is generally contaminated with significant amount of microbial nitrogen (Nocek et al., 1979). This contaminated nitrogen was estimated by incubation of nitrogen free cellulosic materials in the nylon bag under similar conditions and appropriate corrections were made prior to calculating the effective degradability (Negi et al., 1988). The rumen degradable nitrogen (RDN) was calculated based on effective degradability of corrected nitrogen. 
The results of nitrogen degraded at various time intervals are fitted to exponential equation to derive effective degradability using Neway software and the rumen degradable protein (RDP) and rumen undegradable protein (RUP) were calculated accordingly.

\section{Results and Discussion}

\section{In vitro dry matter degradability}

The in vitro degradation of dry matter of WBSG at different incubation hours and effective degradability of WBSG are presented in Tables 1 and 2, respectively.

Disappearance of dry matter (\%) of WBSG was $11.64 \pm 0.36$ at $0 \mathrm{~h}$ which increased to $56.47 \pm 0.85$ at the end of $72 \mathrm{~h}$ indicating that the degradation of DM increased correspondingly with increase in incubation time.

In vitro dry matter degradation of WBSG observed in the present study agreed with the findings of Madrid et al., (2002) who reported the in vitro dry matter disappearance values of brewer's grain at $12,24,48$ and $72 \mathrm{~h}$ were $22.8,34.5,48.1$ and 51.0 per cent, respectively. Similarly, Gao et al., (2015) also reported in situ ruminal DM disappearance of DDGS at $0,12,24,36$ and $48 \mathrm{~h}$ were 11.2 , $20.3,30.5,37.5,42.5$ per cent, respectively in lambs. Batajoo and Shaver (1998) reported that incubation time significantly influenced DM disappearance.

Paya et al., (2012) reported dry matter disappearance from nylon bags incubated in the rumen increased with increasing incubation time and $72 \mathrm{~h}$ incubation time was sufficient for brewer's grain. The variations in dry matter loss might be related to the differences in chemical composition or variations in physical structure, such as the distribution within the tissues of lignified cells (Ramanzin et al., 1991).

The mean rapidly soluble fraction ' $a$ ' of DM of WBSG obtained in the present study was $11.64 \pm 0.36$ per cent, the mean insoluble but slowly degradable fraction ' $\mathrm{b}$ ' was $56.74 \pm$ 0.85 per cent and degradation rate ' $c$ ' was $0.05 \pm 0.01 / \mathrm{h}$. The results of the present study concurred with the findings Batajoo and Shaver (1998) who reported that in situ degradation characteristics of dry matter of the brewer's grain were 14.5 per cent for ' $a$ ' fraction, 57.2 per cent for ' $\mathrm{b}$ ' fractions with degradation rate 'c' of $0.049 / \mathrm{h}$ in dairy cows. Similarly, Promkot et al., (2007) reported that in vitro dry matter degradation parameters of dried brewer's grain were $10.9,51.9$ and 0.031 , for ' $a$ ' and ' $b$ ' fractions and degradation rate 'c', respectively. Kazemi et al., (2014) reported in vitro dry matter disappearance of barley distillers grain were 18.50 per cent, 63.55 per cent, and $0.03 / \mathrm{h}$ for ' $a$ ' and ' $b$ ' fractions and rate of degradation ' $c$ ', respectively with on elevated percentage.

The effective DM degradability of WBSG obtained in the present in vitro study was $40.72 \pm 0.46$ per cent. This result concurred with the finding of Susmel et al., (1989) who reported that the in vitro effective degradability of DM was 40 per cent in brewer's grains. Similarly, Mustafa et al., (2000) also observed that the in vitro effective degradability of DM of barley-based distillers' grains was 43.9 per cent.

The results of the in vitro dry matter degradability as obtained in the present study indicates that the disappearance of dry matter (\%) of WBSG was $11.64 \pm 0.36$ at $0 \mathrm{~h}$ which increased to $56.47 \pm 0.85$ at the end of $72 \mathrm{~h}$. The mean rapidly soluble fraction ' $\mathrm{a}$ ' of DM of WBSG was $11.64 \pm 0.36$ per cent, the mean insoluble but slowly degradable fraction ' $\mathrm{b}$ ' was $56.74 \pm 0.85$ per cent and degradation 
rate 'c' was $0.05 \pm 0.01 / \mathrm{h}$. The effective DM degradability of WBSG was $40.72 \pm 0.46$ per cent.

\section{In vitro nitrogen degradability}

The in vitro nitrogen degradation of WBSG at different incubation hours and effective degradability of WBSG are presented in Tables 8 and 9, respectively.

The nitrogen disappearance (\%) of WBSG was $9.85 \pm 0.58$ at $0 \mathrm{~h}$ which rose to $63.38 \pm$ 0.59 at the end of $72 \mathrm{~h}$ indicating that the degradation of nitrogen increased correspondingly with increase in incubation time. In vitro nitrogen degradation values of WBSG found in the present study concurred with the observations of Majer and Vesely (2012) who reported that the ruminal degradation (\%) of crude protein $(\mathrm{CP})$ in brewer's grain at $0,4,8,16$ and $24 \mathrm{~h}$ of incubation were 4.06, 18.16, 32.40, 38.56 and 50.70 in cows.

The disappearance of rapidly soluble fraction ' $a$ ' of nitrogen in WBSG obtained in the present study was $9.85 \pm 0.57$ per cent, the mean slowly degradable insoluble fraction (b) was $63.38 \pm 0.59$ per cent and degradation rate (c) was $0.03 \pm 0.01 / \mathrm{h}$. The results of the present study concurred with the findings Batajoo and Shaver (1998) who reported that in situ degradabilities of crude protein in the brewer's grain were 16.7 and 64.3 per cent for the ' $a$ ' and ' $b$ ' fractions, respectively with a rate of degradation ' $c$ ' of $0.072 / \mathrm{h}$ in dairy cows. Similarly, Promkot et al., (2007) reported that in vitro crude protein degradation of dried brewer's grain were 13.8 for ' $a$ ' fraction and 53.9 per cent for ' $b$ ' fraction with rate of degradation ' $c$ ' of 0.043/h. However, Majer and Vesely (2012) reported that crude protein disappearance characteristics of wet brewer's grain were 4.31 per cent ' $a$ ' fraction, 53.52 per cent ' $b$ ' fraction and rate of degradation 'c' $0.01 / \mathrm{h}$ in crossbred dairy cows. The lower ' $c$ ' value of nitrogen could be due to the presence of dead microbes in the spent grain taken from the malted processing. These results indicated that the resistance of brewer's grain proteins to ruminal degradation might best be used by combining brewer's grains with non protein nitrogen to increase amino acid flow to the duodenum on high protein diets (Armentano et al., 1986).

The effective nitrogen degradability of WBSG obtained in the present in vitro study was $33.40 \pm 0.71$ per cent. This result concurred with the finding of Majer and Vesely (2012) who reported that the effective ruminal degradability of wet brewer's grain crude protein in vitro was 35.33 per cent and Gao et al., (2015) who reported the effective degradability of crude protein of DDGS in vitro as 32.9 per cent. However, Promkot and Wanapat (2003) presented a slightly higher level (40.9 per cent) of effective degradability of crude protein of brewer's grain in cannulated multiparous Holstein cows. However, Batajoo and Shaver (1998) and Promkot et al., (2007) reported that the effective CP degradability for DBG was 48.9 per cent and 46.8 per cent, respectively.

The effective CP degradability of DBG was lower than other feed ingredients and the DBG contained less rumen degradable protein (Armentano et al., 1986; NRC, 2001). Blethen et al., (1990) stated that the highest percentage of protein of DBG was insoluble fraction $(>40 \%$ of $\mathrm{CP})$. High amounts of insoluble protein could provide high levels of rumen by pass-protein for the host ruminants.

Degradation characteristics of nitrogen of WBSG showed a markedly increased proportion of the degradable ' $b$ ' fraction than the rapidly degradable ' $a$ ' fraction. The major protein fraction of corn and barley are 
prolamins and glutelins which are insoluble and are excellent substrates for deamidation particularly by mammalian tissue transglutaminases (Blethen et al., 1990). Feeding of wet brewer's spent grain increased the RUP which ultimately resulted in higher flow of amino acids to duodenum (Gao et al., 2015).

The mean rumen degradation of crude protein (\%) of wet brewer's spent grain in the present study revealed that $32.72 \pm 0.74$ per cent was rumen degradable protein (RDP) and $54.93 \pm 1.75$ per cent was rumen undegradable protein (RUP). The present study concurred with finding of Gao et al., (2015) who reported that in situ RDP content in DDGS was 32.9 per cent in lambs. However, Belibasakis and Tsirgogianni (1996) reported that wet brewer's grain contained 49.0 per cent RUP. On the contrary, Dhiman et al., (2003) reported that the RUP in wet brewer's grain was 69 per cent of total crude protein in rumen cannulated cows. Gao et al., (2015) also reported that in situ ruminal undegradable protein (RUP) to be 67.1 per cent in lambs.

Addition of RUP to diets of lactating cows increased milk yield (Taylor et al., 1991), milk fat content (Higginbotham et al., 1989) and milk lactose content (Taylor et al., 1991). Brewer's grains are a rich source of protein, especially RUP, which has high concentrations of methionine and lysine (Clark, 1975). Methionine and lysine are the first limiting amino acids for milk yield in dairy cows (Schwab et al., 1976). Further, the RUP in WBSG decreased the excessive production of VFA in the rumen and thus improved the energy balance leading to increasing milk yield and milk fat content (Cozzi and Polan, 1994).

Table.1 Mean $( \pm$ SE) in vitro disappearance of dry matter and nitrogen of WBSG at different time periods

\begin{tabular}{|l|c|c|}
\hline HOURS & $\begin{array}{c}\text { Disappearance* } \\
\text { DM (\%) }\end{array}$ & $\begin{array}{c}\text { Disappearance* } \\
\text { NITROGEN (\%) }\end{array}$ \\
\hline $\mathbf{0}$ & $11.64 \pm 0.36$ & $9.85 \pm 0.58$ \\
\hline $\mathbf{3}$ & $13.14 \pm 0.48$ & $12.04 \pm 0.46$ \\
\hline $\mathbf{6}$ & $15.42 \pm 0.49$ & $16.31 \pm 0.78$ \\
\hline $\mathbf{9}$ & $18.70 \pm 0.67$ & $21.34 \pm 0.39$ \\
\hline $\mathbf{1 2}$ & $22.96 \pm 0.80$ & $26.04 \pm 0.52$ \\
\hline $\mathbf{2 4}$ & $33.50 \pm 0.53$ & $34.45 \pm 0.33$ \\
\hline $\mathbf{3 6}$ & $41.40 \pm 0.60$ & $43.24 \pm 0.51$ \\
\hline $\mathbf{4 8}$ & $49.53 \pm 0.41$ & $54.43 \pm 0.37$ \\
\hline $\mathbf{7 2}$ & $56.47 \pm 0.85$ & $63.38 \pm 0.59$ \\
\hline & $*$ Mean of 5 observations \\
\hline
\end{tabular}


Table.2 Mean ( \pm SE) in vitro dry matter and nitrogen degradation characteristics $(\%)$ of WBSG

\begin{tabular}{|c|c|c|c|c|c|c|c|}
\hline Nutrients & $\begin{array}{c}\text { Degradation } \\
\text { rate/ h } \\
\text { (c) }\end{array}$ & \multicolumn{2}{|c|}{ Degradable } & $\begin{array}{c}\text { Un } \\
\text { degradable }\end{array}$ & $\begin{array}{c}\text { Effective } \\
\text { degradability }\end{array}$ & $\begin{array}{c}\text { Rumen degradation } \\
\text { values (CP \%) }\end{array}$ \\
\cline { 2 - 4 } & Soluble (a) & Insoluble (b) & & & RDP & RUP \\
\hline $\begin{array}{c}\text { Dry } \\
\text { matter }\end{array}$ & $0.05 \pm 0.01$ & $11.64 \pm 0 . .36$ & $56.47 \pm 0.85$ & $31.89 \pm 0.85$ & $40.72 \pm 0.46$ & - & - \\
\hline Nitrogen & $0.03 \pm 0.01$ & $9.85 \pm 0.57$ & $63.38 \pm 0.59$ & $26.77 \pm 0.96$ & $33.40 \pm 0.71$ & $32.72 \pm 0.74$ & $54.93 \pm 1.75$ \\
\hline
\end{tabular}

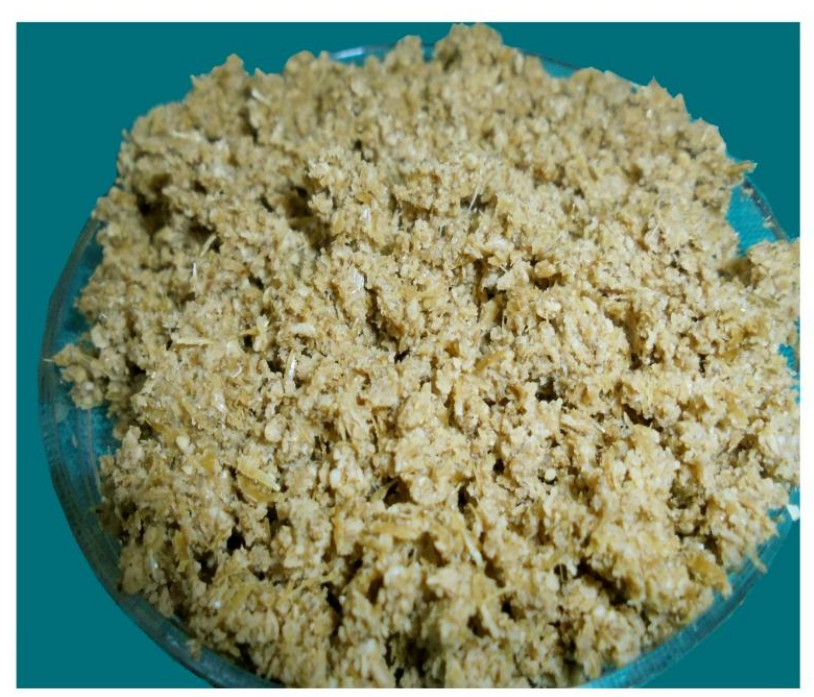

Plate 1. Wet brewer's spent grain used for feeding Salem Black goats

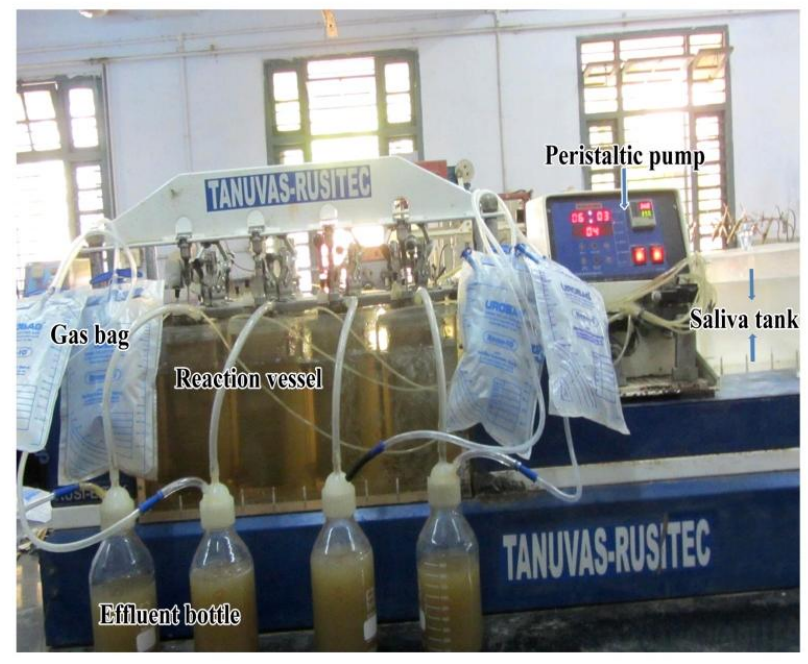

Plate 2. Modified rumen simulation technique (TANUVAS-RUSITEC ) instrument used for in vitro study 
The results of the in vitro nitrogen degradability as obtained in the present study indicates that the disappearance of rapidly soluble fraction ' $a$ ' of nitrogen in WBSG was $9.85 \pm 0.57$ per cent, the mean slowly degradable insoluble fraction (b) was $63.38 \pm$ 0.059 per cent and degradation rate (c) was $0.03 \pm 0.01 / \mathrm{h}$

In conclusion, wet brewer's spent grain (WBSG) is the extracted residue remaining after grains have been fermented during beer making process. In vitro dry matter and nitrogen degradabilities of wet brewer's spent grain were determined using a modified rumen simulation technique (TANUVASRUSITEC $\left.^{\mathrm{TM}}\right)$. The effective DM and nitrogen degradabilities of WBSG were 40.72 and 33.40 per cent, respectively. The mean rumen degradable and undegradable proteins of WBSG were 32.72 and 54.93 per cent, respectively. Wet brewer's spent grain containing 27.47 per cent crude protein with 54.93 per cent rumen undegradable protein (RUP) can be effectively used as a potential bypass protein source in the ruminant diet.

\section{Acknowledgement}

The authors acknowledge the facilities and financial support given to this project by the Dean, Veterinary College and Research Institute, Namakkal and Tamil nadu Veterinary Animal Sciences University, Chennai.

\section{References}

Aguilera, J.F. (1989). Use of Agro-industiral byproducts in the feeding of ruminants. Revista Argentina de production animal, 9: 253-67.

AOAC. (2010). Official Methods of Analysis of Association of Analytical Chemists, -- Edn., Association of Official Analytical Chemists, Benjamin Franklin
Station, Washington D.C.

Armentano, L.E., Herrington, T.A., Polan, I.C.E., Moe, A.J., Herbein, J.H. and Umstadt, P. (1986). Ruminal Degradation of Dried Brewers Grains, Wet Brewers Grains, and Soybean Meal. J. Dairy Sci., 69: 2124-2133.

Belibasakis, N. G. and Tsirgogianni, D. (1996). Effects of wet brewer's grains on milk yield, milk composition and blood components of dairy cows in hot weather. Anim. Feed Sci. Technol., 57: 175-181.

Batajoo, K. K. and Shaver, R. D. (1998). In situ dry matter, crude protein and starch degradabilities of selected grains and by-product. Anim. Feed Sci. Technol., 71: $165-176$.

Blethen, D. B., Wohlt J. E., Jasaitis D. K. and J. L. Evans. (1990). Feed protein fractions: Relationships to nitrogen solubility and degradability. J. Dairy Sci., 73: 1544-1551.

Clark, J.H. (1975). Lactational responses to postruminal administration of proteins and amino acids. J. Dairy Sci., 58: 1178-I 197.

Cozzi, C.I. and Polan, C.E. (1994). Corn gluten meal or dried brewers grains as partial replacement for soybean meal in the diet of Holstein cows. J. Dairy Sci., 77: 825-834.

Czerkawski, J.W. and Breckenridge, G. (1977). Design and development of a long term rumen simulation techniques (RUSITEC). Br.J.Nutri., 38: 371.

Devendra, C. (1983). Small farm systems combining crops and animals. In; Proceedings of the $5^{\text {th }}$ World Conference on Animal Production. 1: 73- 191.

Dhiman, T. R., Bingham, H. R. and Radloff, H. D. (2003). Production Response of Lactating Cows Fed Dried Versus Wet Brewers' Grain in Diets with Similar Dry Matter Content. J. Dairy Sci., 86: 2914-2921. 
Ewing (1997). The Feeds Directory Vol 1. Commodity Products. Context Publications, Leicestershire, England.

Gao, W., Chen, A., Zhang, B., Kong, P., Liu, C. and Zhao, J. (2015). Rumen Degradability and Post-ruminal Digestion of Dry Matter, Nitrogen and Amino Acids of three Protein Supplements Asian Australas. J. Anim. Sci., 28: 485-493.

Hersom, M.J. (2006). Byproduct feed utilization for forage diets. In: $55^{\text {th }}$ Annual Florida Beef Cattle Short Course, Univ. of Florida, Gainesville, pp: 5-14.

Higginbotham, G.E., Torabi, M. and Huber, J.T. (1989). Influence of dietary protein concentration and degradability on performance of cows during hot environmental temperatures. J. Dairy Sci., 72: 2554-2564.

Kazemi M., A. M. Tahmasbi, R. Valizadeh, A. A. Naserian, G. H. Haghayegh and Y. Esmaeil Jami (2014). Studies on the effects of different chemical additives on the nutritive value of ensiled barley distillers' grain (BDG) using in vitro techniques. Direct Research J. Agricul. Food Sci., 2: 19-24

Madrid, J., Dolores, M. and Hernandez, M.F. (2002). In vitro determination of ruminal dry matter and cell wall degradation, and production of fermentation end-products of various by-products. Anim. Res., 51: 189-199.

Majer, V. and Vesely, P. (2012) An assessment of differences in the ruminal degradability and intestinal digestibility of crude protein in brewer's grains and maize draff. Acta univ. agric. et silvic. Mendel. Brun., 1: 97-104.

McDougall, E.I. (1948). Studies on Ruminant Salvia. Biochem. J., 43: 99-109.

Mustafa, A.F, McKinnon, J.J, Christensen, D.A. (2000). Chemical characterization and in situ nutrient degradability of wet distillers' grains derived from barleybased ethanol production. Anim. Feed Sci. Technol., 83: 301-311

National Research Council (2001). Nutrient requirements of dairy cattle. 7 th revised edition. Washington, DC: National Academy Press

Negi, S.S., Singh, B. and Makkar, H.P.S. (1988). An approach to the determination of rumen degradability of nitrogen in low grade roughages and partition of nitrogen there in. J. Agri. Sci. Camb., 111: 487- 494.

Nocek, J.E., Cummins, K.A. and Polan, C.E. (1979). Ruminal disappearance of crude protein and dry matter in feeds and combines effects in formulated rations. J. Dairy Sci., 62:1587-1598.

Orskov, E. R. and Mcdonald, I. (1979). The estimation of protein degradability in the rumen from incubation measurements weighed according to rate of passage. J. Agr. Sci., 92: 499503.

Paya, H., Taghizadeh, A., Lashkari, S. and Shirmohammadi, S. (2012). Evaluation of rumen fermentation kinetics of some by-products using in situ and in vitro gas production technique. Slovak J. Anim. Sci., 45: 127-133.

Promkot C., Wanapat M. and Rowlinson, P. (2007) Estimation of Ruminal Degradation and Intestinal Digestion of Tropical Protein Resources Using the Nylon Bag Technique and the Threestep In vitro Procedure in Dairy Cattle on Rice Straw Diets. Asian-Aust. J. Anim. Sci., 20: 1849 - 1857

Promkot, C. and M. Wanapat. (2003). Ruminal degradation and intestinal digestion of crude protein of tropical protein resources using nylon bag technique and three-step in vitro procedure in dairy cattle. Livest Res Rural Dev., 15: 5-10.

Ramanzin, M., Bailoni, L. and Beni, G. 
(1991). Varietal differences in rumen degradation of barley, wheat and hard wheat straws. Anim. Prod. 53: 143-150.

Schwab, C.G., Satter, L.D. and Clay, A.B. (1976). Response of lactating cows to abomasal infusion of amino acids. $J$. Dairy Sci., 59: 1254-1270.

Susmel, P., B. Stefanon, C.R. Mills, M. and Colitti (1989). The evaluation of PDI concentrations in some ruminant feedstuffs: a comparison of in situ and in vitro protein degradability. Annales de zootechnie. 38: 269-283.

Taylor, R.B., Huber, J.T. and GomezAlarcon, R.A., (1991). Influence of protein degradability and evaporative cooling on performance of dairy cows during hot environmental temperatures. J. Dairy Sci., 74: 243-249.

Thomas, M., Hersom, H., Thrift, T. and Yelich. J. (2013). Wet Brewers' Grains for Beef Cattle. AN241, Animal Sciences Department, Florida Cooperative Extension Service, Institute of Food and Agricultural EDIS. Website at http://edis.ifas.ufl.edu.

West, J.W., Ely, L.O. and Martin, S.A. (1994). Wet brewer's grains for lactating dairy cows during hot, humid weather. J. Dairy Sci., 77: 196-204.

\section{How to cite this article:}

Thavasiappan, V., K. Nanjappan, P. Visha, R. Ezakial Napolean, P. Selvaraj and Doraisamy, K.A. 2020. In vitro Rumen Degradability Study of Wet Brewer's Spent Grain by Modified Rumen Simulation Technique (TANUVAS-RUSITEC ${ }^{\mathrm{TM}}$ ). Int.J.Curr.Microbiol.App.Sci. 9(05):

1118-1127. doi: https://doi.org/10.20546/ijcmas.2020.905.122 